\title{
MARKETING ANALYSIS OF THE RANGE OF ANTIPARASITIC DRUGS REPRESENTED ON THE PHARMACEUTICAL MARKET OF UKRAINE
}

\author{
O.M. Horoshko, M.R. Matushchak, O.I. Zakharchuk, V.M. Drachuk, L.V. Kostyshyn, \\ M.A. Ezhned, V.V. Stepanchuk, I.M. Sakhatska, N.V. Mykhailiuk.
}

HSEE of Ukraine «Bukovinian State Medical University», Chernivtsi

Today, the parasitic diseases are the most common in the world and occupy one of the first places in terms of prevalence and economic losses. The reasons for this situation, according to experts, are low-quality epidemiologically dangerous water and low compliance with sanitary and hygienic standards. The problem of prevention and treatment remains relevant for almost all countries, including Ukraine.

Objective - to conduct a marketing analysis of the range of the domestic pharmaceutical market of antiparasitic drugs.

Material and methods. A marketing analysis was conducted using structural, logical, graphical, systematic and content analysis of data from the State Register of Drugs.

Results. The first stage of the research was to study the range of antiparasitic drugs represented on the pharmaceutical market of Ukraine. It has been determined that in the pharmaceutical market, according to the State Register of Drugs of Ukraine, 22 names of anthelmintic drugs are registered. It has been established that the drugs, supplied to the domestic pharmaceutical market from every corner of the world, are 12 trade names, among which the leading positions in terms of supply are India and France (23\% respectively). Antiparasitic drugs are presented in 3 dosage forms, among which the largest share are tablets - $65.2 \%$, oral suspensions $-30.4 \%$, the least in the pharmaceutical market are phytodrugs with antihelmintic activity (4.6\%). The analysis of the registered antihelmintic drugs has shown that $95.6 \%$ of the study drugs are available by prescription.

Conclusions. It has been found that the largest share of drugs are benzimidazole derivatives, which account for $47.8 \%$ of the total range of the studied drugs, the most common among anthelmintic drugs are dosage forms in tablets (65.2\%).

\section{МАРКЕТИНГОВІ ДОСЛІДЖЕННЯ АСОРТИМЕНТУ ПРОТИПАРАЗИТАРНИХ ЗАСОБІВ, РЕПРЕЗЕНТОВАНИХ НА ФАРМАЦЕВТИЧНОМУ РИНКУ УКРАЇНИ}

О.М. Горошко, М.Р. Матущак, О.І. Захарчук, В.М. Драчук, Л.В. Костишин, М.А. Еэнее, В.В. Степанчук, І.М. Сахацька, Н.В. Михайлюк

На сьогодні паразитарні захворювання є найпоширенішими у світі та посідають одне з перших місиь за розповсюдження та економічними втратами. Причинами такої ситуації, на думку експертів, є неякісна епідеміологічно небезпечна вода та низький рівень дотримання санітарно-гігієнічних норм. Проблема профілактики та лікування залишається актуальною практично для всіх країн, у тому числі й України.

Мета роботи - провести маркетинговий аналіз асортименту вітчизняного фармацевтичного ринку протипаразитарних засобів.

Матеріал та методи. Проведено маркетингове дослідження з використанням структурного, логічного, графічного, системного $і$ контент-аналізу даних Державного реєстру лікарських засобів.

Результати. Першим етапом дослідження стало вивчення асортименту протипаразитарних лікарських засобів, представлених на вітчизняному фармацевтичному ринку. Визначили, щзо на фармацевтичному ринку, за даними Державного реєстру лікарських засобів України, зареєстровано 22 найменування антигельмінтних лікарських засобів. Встановлено, щзо препарати, які постачаються на вітчизняний фармацевтичний ринок з крайн світу, становлять 12 торгових назв, серед яких лідируючі позииії за обсягами постачання припадає на Індію та Францію (по 23\% відповідно). Протипаразитарні засоби представлені в трьох лікарських формах, серед яких найбільшу частку сановлять таблетки - 65,2\%, суспензії оральні - 30,4\%, найменшою мірою на фармацевтичному ринку представлені фітозасоби із антигельмінтною активністю (4,6\%). Аналіз зареєстрованих антигельмінтних лікарських засобів показав, щз 95, 6\% препаратів досліджуваного сегмента підлягають відпуску за рецептом лікаря.

Висновки. Встановлено, щуо найбільшою часткою представлені лікарські засоби
Ключові слова:

helminthiasis, anthelmintic drugs, marketing analysis, phytodrugs

Клінічна та експериментальна патологія 2020. T.19, №3(73). C.25-31.

DOI:10.24061/1727-4338. XIX.3.73.2020.4

E-mail:

gorolesya@ukr.net

\section{Ключові слова:}

гельмінтози, антигельмінтні засоби, маркетинговий аналіз, фітозасоби.

Клінічна та експериментальна патологія 2020. T.19, №3(73). C.25-31. 
похідні бензимідазолу, щзо разом становлять 47,8\% від загальної кількості досліджуваного асортименту, найпоширенішими серед антигельмінтних засобів є лікарськими формами у таблетках (65,2\%).

\section{Ключевые слова: гельминтозы, анти- гельминтные сред- ства, маркетинговой анализ, фитопрепа- pambl.}

Клиническая и экспериментальная патология T.19, №3 (73). C.25-31.

\section{МАРКЕТИНГОВЫЕ ИССЛЕДОВАНИЯ АССОРТИМЕНТА ПРОТИВОПАРАЗИТАРНЫХ СРЕДСТВ, ПРЕДСТАВЛЕНЫХ НА ФАРМАЦЕВТИЧЕСКОМ РЫНКЕ УКРАИНЫ}

\author{
А.М. Горошко, М.Р. Матущак, А.И. Захарчук, В.М. Драчук, Л.В. Костишин, \\ М.А. Эжнед, В.В. Степанчук, И.М. Сахацкая, Н.В. Михайлюк
}

На сегодня паразитарные заболевания являются самыми распространенными в мире и занимают одно из первых мест по распространению и экономическим потерям. Причинами такой ситуации, по мнению экспертов, является некачественная эпидемиологически опасная вода, низкий уровень соблюдения санитарно-гигиенических норм. Проблема профилактики и лечения остается актуальной практически для всех стран, в том числе и Украиньл.

Цель работы - провести маркетинговый анализ ассортимента отечественного фармацевтического рынка противопаразитарных средств.

Материал и методы. Проведено маркетинговое исследование с использованием структурного, логического, графического, системного и контент-анализа данных Государственного реестра лекарственных средств.

Результаты. Первым этапом исследования стало изучение ассортимента противопаразитарных лекарственных средств, представленных на отечественном фармацевтическом рынке. Проведя маркетинговое исследование, определили, что на фармацевтическом рынке, по данным Государственного реестра лекарственных средств Украины, зарегистрировано 22 наименования антигельминтных лекарственных средств. Установлено, что препараты, поставляемые на отечественный фармацевтический рынок из стран мира, составляют 12 торговых наименований, среди которых лидирующче позищии по объемам поставок приходится на Индию и Франциию (по 23\% соответственно). Противопаразитарные средства представлень в трёх лекарственных формах, среди которых наибольшую долю составляют таблетки - 65,2\%, суспензии оральные - 30,4\%, в наименьшей степени на фармачевтическом рынке представлены фитосредства с антигельминтной активностью (4,6\%). Анализ зарегистрированных антигельминтных лекарственных средств показал, что 95,6\% препаратов исследуемого сегмента - 22 лекарственных средства подлежит отпуску по рейепту врача.

Выводы. Наибольшей долей представлень лекарственнье средства производные бензимидазола, которые вместе составляют 47,8\% от общего количества исследуемого ассортимента, наиболее распространенныли среди антигельминтных средств являются лекарственные формы в таблетках (65,2\%).

\section{Introduction}

Medical problems are complicated by parasitic diseases, the occurrence of which is proportional to the deterioration of the environmental situation and the decline of the sanitary culture of the population. Today, parasitic diseases are the most common in the world and occupy one of the first places in terms of economic losses [1]. According to the World Health Organization, 14 million, among the 50 million people who die each year, are diagnosed with parasitic diseases $[2,3]$. One of the most common diseases in the world is helminthiasis, which accounts for almost $90 \%$ of parasites, which is approximately: ascariasis - 1 billion 450 million inhabitants, trichocephaly - 1 billion 50 million, other nematodes - 1 billion 300 million [4,5].

The situation is also disappointing in Ukraine, where up to 500,000 new patients with parasitosis are registered annually, most often such helminthiasis as enterobiasis (75\%), ascariasis $(20 \%)$, the rest of trematodes, trichocephaly and hymenolepidosis [6,7]. The level of helminth infestation can be significantly higher than that registered due to poor diagnosis.

The reasons for this situation, according to experts, are primarily that $25 \%$ of the world's population consumes low-quality epidemiologically dangerous water, and $66 \%$ - deprived of sanitary and hygienic facilities [8], the morbidity among the population of Ukraine due to drinking water pollution, open water, soil invasive eggs $[9,10]$. Parasitic diseases occupy a significant share in the structure of human diseases, so it is important to study infectious and invasive diseases and get acquainted with the features of their prevention and treatment. This problem remains relevant for almost all countries, including Ukraine.

\section{Objective}

To conduct a marketing analysis of the domestic pharmaceutical market range of antiparasitic drugs. 


\section{Material and methods}

A marketing analysis was conducted using structural, logical, graphical, systemic and content analysis of data from the State Register of Drugs. The market analysis was carried out taking into account international nonproprietary names and trade names, dosage form, country and manufacturer, as well as the main pharmacological characteristics

\section{Results and discussion}

In the parasitic diseases spread the factors, that cause infection of the population, especially the level of contamination by the soil pathogens and water parasites, are of great importance and the territory of Ukraine has favorable environmental conditions for widespread diseases of this group. Sources of invasive eggs and larvae are the environment, insects, humans, domestic and wild animals that carry large amounts of helminths [8]. During life, almost everyone in our country has suffered from an invasive disease, which in most cases is not accompanied by severe clinical symptoms. Symptoms such as tiredness, weakness, restless sleep, appetite loss, short-term abdominal pain, etc. are not associated with parasitosis in general practitioners. The patients are diagnosed late and not prescribed a special examination and do not undergo it. In many cases the cause is not identified. However, it is known that helminths and the simplest intestinal parasites today are a problem of global importance and pose a serious danger to humans, manifesting itself in the form of allergies, immunosuppression, avitaminosis, lesions of the gastrointestinal tract and other organs. In addition, as a result of the negative impact of parasite metabolites in humans, a predisposition to a wide range of diseases is formed [11]. For the timely treatment of helminth infections it is important to provide the population with effective, high quality, safe and affordable antiparasitic drugs, so our goal was to analyze the range of anthelmintic drugs in the pharmaceutical market of Ukraine.

The first stage of the research was to study the range of antiparasitic drugs on the domestic pharmaceutical market. After conducting a marketing study, it was determined that in the pharmaceutical market, according to the State Register of Drugs of Ukraine, 22 names of anthelmintic drugs were registered (Table 1).

The list of anthelmintic drugs registered in Ukraine

Table 1

\begin{tabular}{|c|c|c|c|c|}
\hline \begin{tabular}{l} 
№ \\
I\} \backslash \mathbf { I I } & Drugs & Dosage form & ATC code & Manufacturer, country \\
\hline \multicolumn{5}{|c|}{ Drugs used in case of nematodes } \\
\hline \multicolumn{5}{|c|}{ Benzimidazole derivatives } \\
\hline 1. & Vermox & tablets & P02C A01 & Gideon Richter AT, Romania \\
\hline 2. & Vermox & tablets & P02C A01 & Janssen cilag, Italy \\
\hline 3. & Albela & tablets & P02C A03 & Kusum pharm LLC, Ukraine \\
\hline 4. & Albendazole & chewable tablets & P02C A03 & Medi Biotek Ltd, India \\
\hline 5. & Albendazole & chewable tablets & P02C A03 & Ternopharm LLC, Ukraine \\
\hline 6. & Aldazole & tablets & $\mathrm{P} 02 \mathrm{C} \mathrm{A03}$ & JSC "Kyiv Vitamin Plant", Ukraine \\
\hline 7. & Angelmex & chewable tablets & P02C A03 & Agropharm LLC, Ukraine \\
\hline 8. & Vormil & chewable tablets & P02C A03 & Mili Healthcare, United Kingdom \\
\hline 9. & Vormil & oral suspension & P02C A03 & Madras Pharmaceuticals, India \\
\hline 10. & Zentel & tablets & P02C A03 & GlaxoSmithKline, South Africa \\
\hline 11. & Zentel & oral suspension & P02C A03 & Farmaclair, France \\
\hline 12. & Pharmox & oral suspension & P02C A03 & "Pharmaceutical factory" DKP LLC, Ukraine \\
\hline \multicolumn{5}{|c|}{ Piperazine derivatives } \\
\hline 13. & $\begin{array}{l}\text { Piperazini } \\
\text { adipinatum-Darnitsa }\end{array}$ & tablets & P02C B01 & $\begin{array}{l}\text { PJSC "Pharmaceutical firm" Darnitsa", } \\
\text { Ukraine }\end{array}$ \\
\hline \multicolumn{5}{|c|}{ Tetrahydropyrimidine derivatives } \\
\hline 14. & Helmintox & tablets & $\mathrm{P} 02 \mathrm{C} \mathrm{C01}$ & Innothera Chouzy, France. \\
\hline 15. & Helmintox & oral suspension & $\underline{\mathrm{P} 02 \mathrm{C} \mathrm{C} 01}$ & Innothera Chouzy, France. \\
\hline 16. & Pyrantel Polpharma & oral suspension & $\underline{\mathrm{P} 02 \mathrm{C} \mathrm{C} 01}$ & $\begin{array}{l}\text { Medana Pharma Joint Stock Company, } \\
\text { Poland }\end{array}$ \\
\hline 17. & Pyrantel & oral suspension & $\underline{\mathrm{P} 02 \mathrm{C} \mathrm{C} 01}$ & Kusum pharm LLC, Ukraine \\
\hline 18. & Pyrantel & tablets & $\underline{\mathrm{P} 02 \mathrm{C} \mathrm{C} 01}$ & Kusum healthcare PVT. LTD., India \\
\hline 19. & Pyrantelum-Vishpha & oral suspension & $\underline{\mathrm{P} 02 \mathrm{C} \mathrm{C} 01}$ & "Pharmaceutical factory" DKP LLC, Ukraine \\
\hline \multicolumn{5}{|c|}{ Imidazothiazole derivatives } \\
\hline 20. & Decaris & tablets & P02C E01 & OJSC Gideon Richter, Hungary \\
\hline 21. & Levamisole-Zdorovya & tablets & $\underline{\mathrm{P} 02 \mathrm{C} \mathrm{E} 01}$ & $\begin{array}{l}\text { Pharmaceutical company "Zdorovye" LLC, } \\
\text { Ukraine }\end{array}$ \\
\hline \multicolumn{5}{|c|}{ Other antinematode drugs } \\
\hline 22. & Flores Tanaceti & flowers & $\underline{\mathrm{P} 02 \mathrm{C} \mathrm{X} 10 * *}$ & PJSC "Liktravy", Ukraine \\
\hline
\end{tabular}
\end{tabular}


The group of drugs under study, according to the component, is represented by monocomponent drugs.

The next stage of the studied range was the analysis of drugs registered in Ukraine according to the country of manufacture. According to the results of the analysis, it is established that they are supplied to the domestic pharmaceutical market from every corner of the world and make up 12 trade names, among which the leading positions in terms of supply are India and France (13,6\% respectively) (Fig. 1).

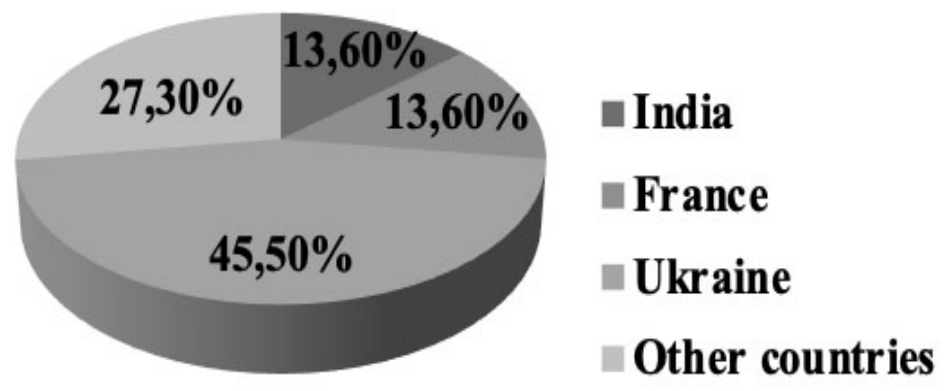

Figure 1. Percentage of manufacturing facilities of anthelmintic drugs by country

In Ukraine, 22 researched drugs are sold, taking into account the dosage forms. The ratio of trade names of domestic and foreign production is $10(45.45 \%)$ and 12 (54.55\%), respectively (Fig.2).

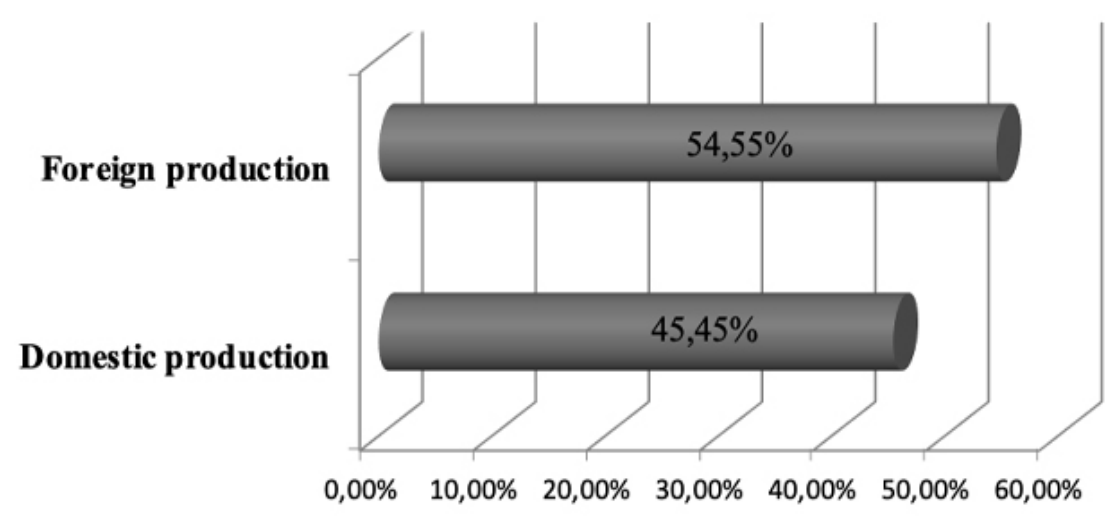

Figure 2. The ratio of trade names of anthelmintic drugs of domestic and foreign production

The next stage of our research was to study the range of antiparasitic drugs by dosage form. According to the results of the study, all drugs are presented in 3 dosage forms, among which the largest share are tablets $-65.2 \%$, oral suspensions $-30.4 \%$, the least in the pharmaceutical market are anthelmintic phytodrugs (4.6\%) (Fig.3).

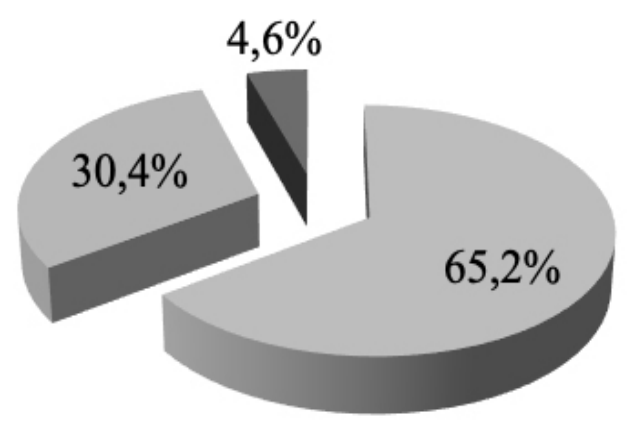

\section{Tablets}

Oral suspension

Figure 3 Percentage of anthelmintics by release form 
Analysis of the registered anthelmintic drugs showed that most drugs in the study segment - 22 drugs (95.6\%) - are released by prescription. Over-the-counter drugs include only 1 name - Flores Tanaceti

Thus, drugs in the pharmaceutical market for the helminthic infestations treatment are mostly imported and not always economically available to the population of Ukraine. Drugs from foreign manufacturers are often quite expensive, and the majority of people are unable to buy them to treat certain diseases or maintain health at a certain level.

\section{Conclusions}

According to the results of marketing research, it was established that 15 trade names were registered in Ukraine. The ratio of the main registered subgroups of international non-proprietary names according to the ATC classification has been studied. Benzimidazole derivatives, which account for $47.8 \%$ of the total range of the drugs under study, are found to be the largest share of drugs. The ratio of antiparasitic drugs trade names of foreign and domestic production is $56.5 \%$ and $43.5 \%$, respectively, which generally reflects the general market trends in the pharmaceutical market. Studies have shown that the most common dosage forms of anthelmintic drugs are tablets $(65.2 \%)$.

\section{Prospects for the further researches}

Despite the wide range of drugs on the Ukrainian pharmaceutical market, the population is insufficiently provided with drugs for the parasitic diseases treatment. Therefore, it is promising to study the effectiveness of medicinal plants, phytomedicines and dietary supplements, both for the prevention and enhancement of treatment of parasitic diseases.

\section{Список літератури}

1. Станкевич ВВ, Тарабарова СБ. Санітарно-гігієнічна проблема забруднення гельмінтами об'єктів навколишнього середовища в Україні (огляд). Гігієна населених місць. 2015;66:85-9.

2. Мухарська ЛМ, Некрасова ЛС, Свита ВМ. Актуальні проблеми паразитарних хвороб в світі, Україні та шляхи вирішення. Инфекционный контроль. 2010;1:30-1.

3. Сорокман ТВ, Молдован ПМ. Оцінка ефективності лікування кишкової форми аскаридозу в дітей. Актуальна інфектологія. 2019;7(5):264-8. doi: 10.22141/2312-413x.7.5.2019.183706

4. Рамочна програма контролю і профілактики геогельмінтозів в Європейському регіоні ВООЗ, 2016-2020 pр. Копенгаген: Всесвітня організація охорони здоров'я; 2016. 40 с.

5. Іванько ОМ, Кожокару АА, Колос ЛА, Філіпенко ЛІ, Мельник ОВ. Епідеміолого-географічні аспекти гельмінтозів на території України. Проблеми військової охорони здоров'я. 2012;31:116-24.

6. Сєрих НО, Боєва СС, Стрижак НВ, Таллер ОЮ, Шаршакова ОС. Поширення яєць гельмінтів в об'єктах довкілля (грунті та воді) на території заплав Сіверського Дінця. Запорожский медицинский журнал. 2018;20(4):574-7. doi: https://doi. org/10.14739/2310-1210.2018.4.135349

7. Бодня КІ. Діагностика та лікування паразитарних інвазій у дітей. Сучасна гастроентерологія. 2006;6:64-7

Клінічна та експериментальна патологія. 2020. Т.19, № 3 (73)
8. Станкевич ВВ, Тарабарова СБ, Черевко ОМ. Гігієнічна проблема забруднення гельмінтами довкілля та профілактичні заходи боротьби 3 гельмінтозами (огляд). Гігієна населених місць. 2019;69:237-42. doi: https:/doi. org/10.32402/hygiene2019.69.237

9. Волошина НО. Стратегія еколого-раціонального контролю паразитарного забруднення. Наукові доповіді НУБіП України [Інтернет]. 2012[цитовано 2020 Жов 15];2. Доступно: http:// enpuir.npu.edu.ua/bitstream/123456789/12967/1/V\%201.pdf

10. Ерофеева ВВ, Доронина ГН. Оценка эколого-эпидемической опасности распространения яиц гельминтов в почвах городских территорий. Здоровье и образование в XXI веке [Интернет]. 2017[цитировано 2020 Окт 12];19:208-10. Доступно: https://clinical-journal.co.uk/ gallery/2017p-19-10-208-210.pdf

11. Захарчук ОІ. Стан гуморальної ланки імунітету у дітей хворих на токсокароз. Український журнал медицини, біології та спорту. 2020;5(4):150-4. doi: 10.26693/jmbs05.04.150

\section{References}

1. Stankevich VV, Tarabarova SB. Sanitarno-hihiienichna problema zabrudnennia hel'mintamy ob'iektiv navkolyshn'oho seredovyscha $\mathrm{v}$ Ukraini (ohliad) [Sanitaryand-hygienic problem of contamination the helmints of objects of environment is in Ukreine (review)]. Hygiene of populated places. 2015;66:85-9. (in Ukrainian).

2. Mukhars'ka LM, Nekrasova LS, Svyta VM. Aktual'ni problemy parazytarnykh khvorob v sviti, Ukraini ta shliakhy vyrishennia [Current problems of parasitic diseases in the world, Ukraine and solutions]. Infektsionnyy kontrol'. 2010;1:30-1. (in Ukrainian).

3. Sorokman TV, Moldovan PM. Otsinka efektyvnosti likuvannia kyshkovoi formy askarydozu $\mathrm{V}$ ditei [Evaluation of the effectiveness of the treatment of intestinal ascariasis in children]. Aktual'naâ Infektologiâ. 2019;7(5):264-8. doi: 10.22141/2312-413x.7.5.2019.183706 (in Ukrainian).

4. Ramochna prohrama kontroliu i profilaktyky heohel'mintoziv v Yevropeis'komu rehioni VOOZ, 2016-2020 rr. [Framework Program for Control and Prevention of Geohelminthiasis in the WHO European Region, 2016-2020]. Kopenhahen: Vsesvitnia orhanizatsiia okhorony zdorov'ia; 2016. 40 p. (in Ukrainian).

5. Ivanko O, Kozhokaru A, Kolos L, Filipenko L, Melnik A. Epidemioloho-heohrafichni aspekty hel'mintoziv na terytorii Ukrainy [Epidemiological and geographical aspects of helminthiasis in Ukraine]. Problemy viis'kovoi okhorony zdorov'ia. 2012;31:11624. (in Ukrainian).

6. Sierykh NO, Boieva SS, Strizhak NV, Taller OYu, Sharshakova OS. Poshyrennia yaiets' hel'mintiv v ob'iektakh dovkillia (grunti ta vodi) na terytorii zaplav Sivers'koho Dintsia [Dissemination of helminth eggs in the environmental objects (soil and water) in the territory of the Siversky Donets terraces]. Zaporozhye medical journal. 2018;20(4):574-7. doi: https://doi.org/10.14739/23101210.2018.4.135349 (in Ukrainian).

7. Bodnya KI. Diahnostyka ta likuvannia parazytarnykh invazii $\mathrm{u}$ ditei [Diagnostics and treatment of infestations in children]. Suchasna hastroenterolohiia. 2006;6:64-7. (in Ukrainian).

8. Stankevych VV, Tarabarova SB, Cherevko OM. Hihiienichna problema zabrudnennia hel'mintamy dovkillia ta profilaktychni zakhody borot'by z hel'mintozamy (ohliad) [The hygienic issue of helminth pollution of the environment and helmenthiasis preventive measures (review)]. Hygiene of populated places. 2019;69:237-42. doi: https://doi.org/10.32402/ hygiene2019.69.237 (in Ukrainian).

9. Voloshina N. Stratehiia ekoloho-ratsional'noho kontroliu ISSN 1727-4338 https://www.bsmu.edu.ua 
parazytarnoho zabrudnennia [Strategy of ecology-improvemently control of the environment from parasitic contamination]. Naukovi dopovidi NUBiP Ukrainy [Internet]. 2012[tsytovano 2020 Zhov 15];2. Dostupno: http://enpuir.npu.edu.ua/ bitstream/123456789/12967/1/V\%201.pdf (in Ukrainian).

10. Erofeeva VV, Doronina GN. Otsenka ekologo-epidemicheskoy opasnosti rasprostraneniya yaits gel'mintov $\mathrm{V}$ pochvakh gorodskikh territoriy [Assessment of the ecological and epidemic hazard of helminth eggs spread in the soils of urban areas].
Zdorov'e i obrazovanie v XXI veke [Internet]. 2017[tsitirovano 2020 Okt 12];19:208-10. Dostupno: https://clinical-journal. co.uk/gallery/2017p-19-10-208-210.pdf (in Russian).

11. Zakharchuk OI. Stan humoral'noi lanky imunitetu u ditei khvorykh na toksokaroz [The State of the Humoral Link of Immunity in Children with Toxocariasis]. Ukrains'kyi zhurnal medytsyny, biolohii ta sportu. 2020;5(4):150-4. doi: 10.26693/ jmbs05.04.150 (in Ukrainian).

\section{Відомості про авторів}

Горошко О.М. - к.фарм.н., доцент кафедри фармацевтичної ботаніки та фармакогнозії Вищого державного навчального закладу України «Буковинський державний медичний університет», м. Чернівці, Україна.

Матущак М.Р. - асистент кафедри фармацевтичної ботаніки та фармакогнозії Вищого державного навчального закладу України «Буковинський державний медичний університет», м. Чернівці, Україна.

Захарчук О.І. - д.мед.Н., професор, завідувач кафедри фармацевтичної ботаніки та фармакогнозії Вищого державного навчального закладу України «Буковинський державний медичний університет», м. Чернівці, Україна.

Драчук В.М. - к.фарм.н., асистент кафедри фармакології Вищого державного навчального закладу України «Буковинський державний медичний університет», м. Чернівці, Україна.

Костишин Л.В. - асистент кафедри фармацевтичної ботаніки та фармакогнозії Вищого державного навчального закладу України «Буковинський державний медичний університет», м. Чернівці, Україна.

Ежнед М.А. - асистент кафедри фармацевтичної ботаніки та фармакогнозії Вищого державного навчального закладу України «Буковинський державний медичний університет», м. Чернівці, Україна.

Степанчук В.В. - к.мед.д., доцент кафедри фармацевтичної ботаніки та фармакогнозії Вищого державного навчального закладу України «Буковинський державний медичний університет», м. Чернівці, Україна.

Сахацька I.M. - к.фарм.н, старший викладач кафедри фармацевтичної ботаніки та фармакогнозії Вищого державного навчального закладу України «Буковинський державний медичний університет», м. Чернівці, Україна.

Михайлюк Н.В. - викладач кафедри фармацевтичної ботаніки та фармакогнозії Вищого державного навчального закладу України «Буковинський державний медичний університет», м. Чернівці, Україна.

\section{Информация об авторах}

Горошко А.М. - к.фарм.н., доцент кафедры фармацевтической ботаники та фармакогнозии Высшего государственного учебного заведения Украины «Буковинский государственный медицинский университет», г. Черновцы, Украина.

Матущак М.Р. - ассистент кафедры фармацевтической ботаники та фармакогнозии Высшего государственного учебного заведения Украины «Буковинский государственный медицинский университет», г. Черновцы, Украина.

Захарчук А.И. - д.мед.н., профессор, заведующий кафедры фармацевтической ботаники та фармакогнозии Высшего государственного учебного заведения Украины «Буковинский государственный медицинский университет», г. Черновцы, Украина.

Драчук В.М. - к.фарм.н., ассистент кафедры фармакологии Высшего государственного учебного заведения Украины «Буковинский государственный медицинский университет», г. Черновцы, Украина.

Костишин Л.В. - ассистент кафедры фармацевтической ботаники та фармакогнозии Высшего государственного учебного заведения Украины «Буковинский государственный медицинский университет», г. Черновцы, Украина.

Эжнед М.А. - ассистент кафедры фармацевтической ботаники та фармакогнозии Высшего государственного учебного заведения Украины «Буковинский государственный медицинский университет», г. Черновцы, Украина.

Степанчук В.В. - к.мед.д., доцент кафедры фармацевтической ботаники та фармакогнозии Высшего государственного учебного заведения Украины «Буковинский государственный медицинский университет», г. Черновцы, Украина.

Сахацькая И.М. - к.фарм.н, старший преподаватель кафедры фармацевтической ботаники та фармакогнозии Высшего государственного учебного заведения Украины «Буковинский государственный медицинский университет», г. Черновцы, Украина.

Михайлюк Н.В. - преподаватель кафедры фармацевтической ботаники та фармакогнозии Высшего государственного учебного заведения Украины «Буковинский государственный медицинский университет», г. Черновцы, Украина.

\section{Information about authors}

Horoshko O.I. - Candidate of Pharmaceutical Sciences, Associate Professor at the Department of pharmaceutical 
botany and pharmacognosy, Bukovinian State Medical University, Chernivtsi.

Matushchak M.R. - Assistant Professor at the Department of pharmaceutical botany and pharmacognosy, Bukovinian State Medical University, Chernivtsi.

Zakharchuk O.I. - Doctor of Medical Sciences, Professor, Head of the Department of pharmaceutical botany and pharmacognosy, Bukovinian State Medical University, Chernivtsi.

Drachuk V.M. - Candidate of Pharmaceutical Sciences, Assistant Professor at the Pharmacology Department, Bukovinian State Medical University, Chernivtsi.

Kostyshyn L.V. - Assistant Professor at the Department of pharmaceutical botany and pharmacognosy, Bukovinian State Medical University, Chernivtsi.

Ezhned M.A. - Assistant Professor at the Department of pharmaceutical botany and pharmacognosy, Bukovinian State Medical University, Chernivtsi.

Stepanchuk V.V. - Candidate of Medical Sciences, Associate Professor at the Department of pharmaceutical botany and pharmacognosy, Bukovinian State Medical University, Chernivtsi.

Sakhatska I.M. - Candidate of Pharmaceutical Sciences, Senior Lecturer at the Department of pharmaceutical botany and pharmacognosy, Bukovinian State Medical University, Chernivtsi.

Mykhailiuk N.V. - Teacher at the Department of pharmaceutical botany and pharmacognosy, Bukovinian State Medical University, Chernivtsi. 